症例

直腸癌手術後 12 年目に人工肛門に発生した腺腫内癌の 1 例

\begin{tabular}{|c|c|c|c|c|c|c|c|c|c|c|c|c|}
\hline \multirow{2}{*}{$\begin{array}{l}\text { 竹 } \\
\text { - }\end{array}$} & \multicolumn{12}{|c|}{ 東大阪市立中央病院外科 } \\
\hline & 内 & 幸 & 康 & 南 & & 俊之介 & 杉 & 野 & 盛 & 規 & 柏 & 井 \\
\hline 武 & 田 & & 学 & 畑 & 中 & $\begin{array}{l}\text { 信 良 } \\
\text { 市立豊口 }\end{array}$ & & $\begin{array}{l}\text { 田 } \\
\text { 序理 }\end{array}$ & 博 & 志 & & \\
\hline
\end{tabular}

人工肛門に腺癌が新発生することはきわめて稀である。症例は56歳の男性で, 1975年 に直腸癌のため Miles 手術，1977年に盲腸癌のため結腸右半切除術を施行されており， いずれす治傯切除であった。術後は再発徽候を認めなかった，1987年，人工肛門の出血 を主訴に来院し，同部に母指頭大の腫瘤を認めた．生検にて腺腫内癌と診断されたため， 人工肛門断端より結腸を剝離遊離し腫痬口側縁より $1 \mathrm{~cm} の$ 部位で結腸を環状切除した。 病理組織検査にて腺腫の中心に粘膜下層に達する粘液癌を認めた。人工肛門に腫癌が発 生したといら報告は, 潰場性大腸炎症例で 3 例, Miles 手術術後に1 例報告されているの みである．本症例のごとく人工肛門に腺腫内癌が発生した報告はなく，若干の文献的考 察を加え報告する。

索引用語：異時性多発大腸癌, 人工肛門, 腺腫内癌

\section{緒言}

人工肛門に腺癌が新発生したといら報告は1966年に

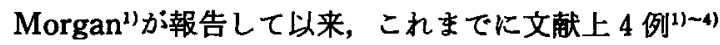
が報告されているのみである。人工肛門部に腺腫内癌 が発生した報告はいまだない，今回，直腸癌に対する Miles 手術術後12年目に人工肛門に腺腫内癌が発生し た症例を経験したので，若干の文献的考察を加え報告 する.

\section{患者：56歳, 男性.}

主訴: 人工肛門の出血。

家族歴：兄弟 4 人すべてに消化器癌の既往がある. 実弟にS 状結腸，横行結腸の多発結腸癌ならびに胃癌 との重複癌， 2 人の妹のうち一方が直腸ならびに盲腸 の多発大腸癌で，他方は上行結腸癌であった。 また実 母は子宮内膜癌であった。

既往歴：1975年，44歳の時に直晹癌（stage 1) のた めMiles 手術，1977年，46歳の時に盲腸癌 (stage 2) のため結腸右半切除術を施行していた．いずれす絶対 治澺切除であった。
現病歴：1986年 7 月, 人工肛門粘膜に直径約 $3 \mathrm{~mm}$ の 隆起性病変に気ついた。徐々に増大し，翌年 3 月には 母指頭大となり，また同部より度々出血するため，4 月17日，約 2 年 2 カ月ぶりに当院を受診した。精密検 查予定であったか，脳内出血のため他院で血属除去術 を受けた後，6月1日当科に入院した。

入院時現症：体格中等度，栄盖状態良好．蔶血，黄 疸は認めず，腹部は平坦で腫瘤は触知せず，腹部正中 に手術痕, 及び左下腹部に人工肛門が造設されていた。 人工肛門断端部から約 $1 \mathrm{~cm}$ 口側に，母指頭大の腫瘤を 認めた。腫瘤は広基性で表面は凹凸不整であったが色 調は周囲正常粘膜と差を認めなかった(図 1).その他， 左不全片麻㿎以外，特記すべき所見を認めなかった。

入院時検查所見 : 末梢血一般検查, 生化学検查共に 異常を認めず。CEA は1.6ng/mlであった。 また，注 腸 X 線検査では異常所見を認めなかった。

入院後経過：6月 2 日に生検を行い focal cancer in papillotubular adenoma と診断されたため，6月19日 手術を行った。

手術所見：硬膜外麻醉下，人工肛門断端を全周性 $儿$

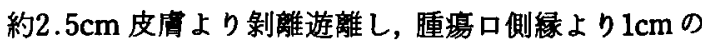
距離で結腸を環状切除した（図2）。 

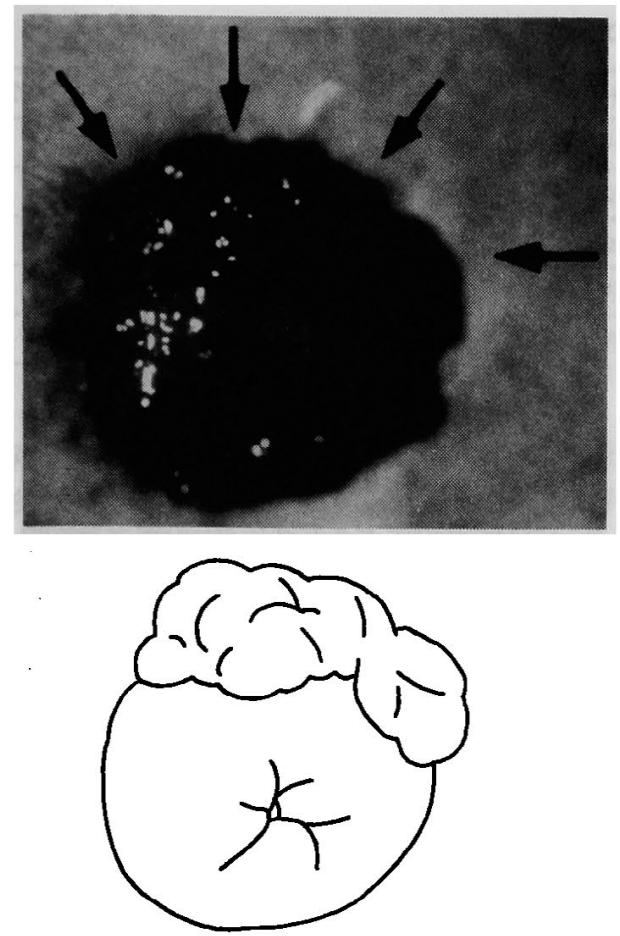

図 1 入院時の人工肛門部(写真と模式図)：矢印は腫 第を示す。

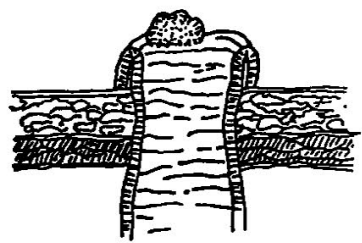

1. 術前の人工肛門

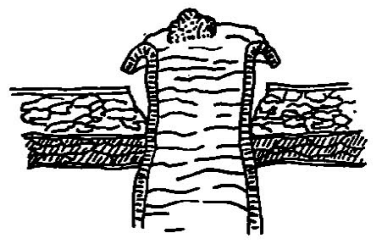

2. 人工肛門断端を全周性に䟝離
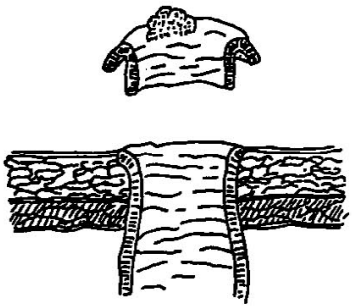

3. OW を $1 \mathrm{~cm}$ 確保し環状切除

图 2 手術の模式図

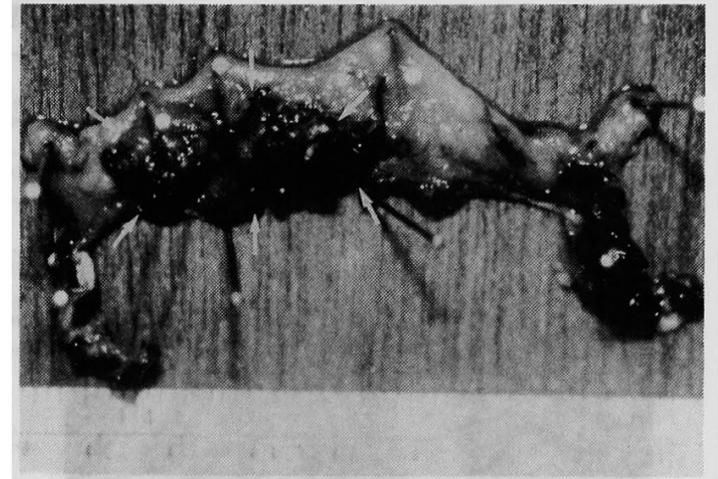

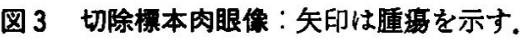

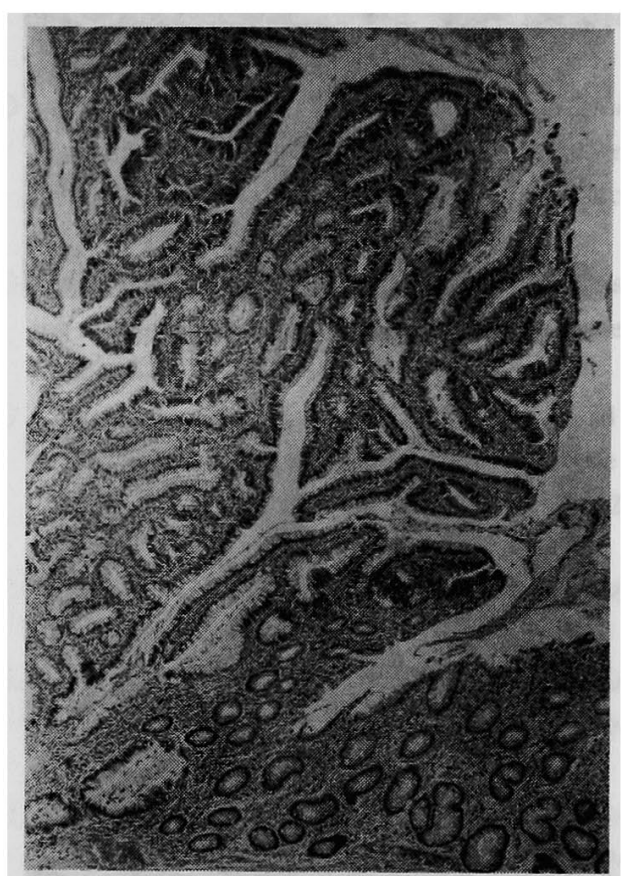

图 4 病理組織像(H.E 染色, 弱拡大像)：腫痬の大部 分は異型度の乏しい乳頭腺管腺嗹であった。

肉眼所見：腫瘤は広基性ポリーブで，大きさは， $3.5 \times 1.3 \times 0.5 \mathrm{~cm}$ であった（図 3 ）。

病理組織所見：病変部は主として異型度のそしい乳 頭腺管状腺腫からなっていた(図 4，5)。そての心部 に約 $20 \%$ 部分に異型度の強い腺管を認め, 一部粘膜 下組織に浸潤し(図 6，7)，その部では粘液癌の像を 呈していた。切除断端には腫場を認めなかった。

以上の所見より, 腺腫内癌と診断された。

術後経過：術後 2 年を経過したが，人工肛門を含め 腹部に再発徵候を認めない。 


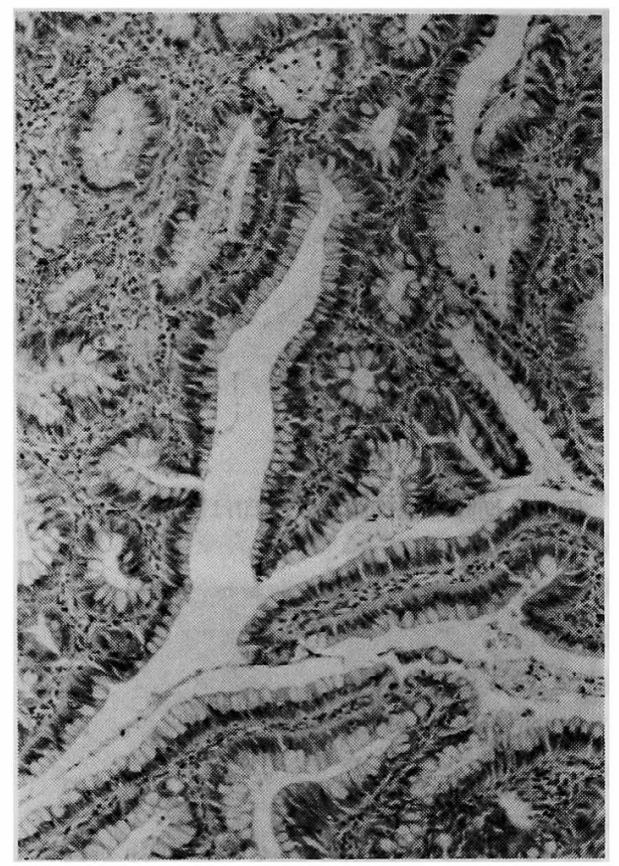

図 5 病理組織像（図 4 の強抎大像）。

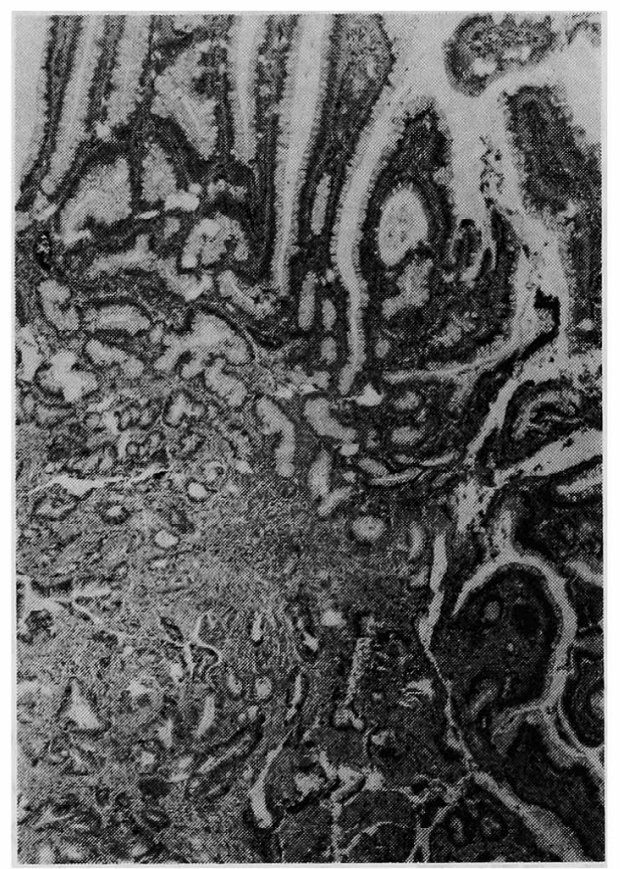

图 6 病理組織像 (H.E 染色, 弱払大像)：腫湯の一部 では異型度の強い腺管が増殖し，粘膜下組織に浸潤 していた.

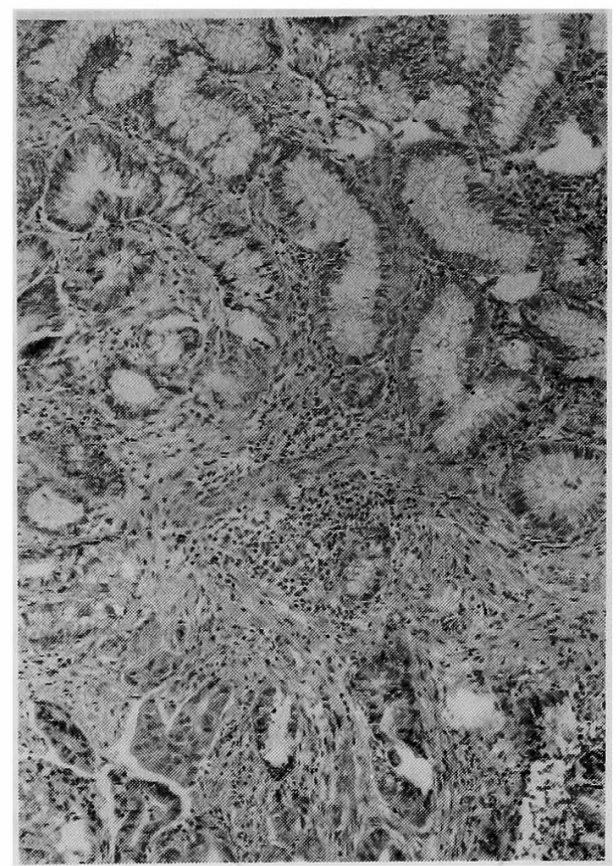

図 7 病理組織像(因 6 の強拡大像)：粘膜下層に浸潤 した粘液癌像.

\section{考察}

同時性にせよ異時性にせよ大腸に癌が多発すること はまれではない，第16回大腸癌研究会のアンヶート調 査)では1971年より1980年までの集計24616例の結果, 大腸多発癌の頻度は同時性 $3.2 \%$, 異時性 $1.3 \%$ であっ た，異時性大腸癌の占居部位については，第 1 癌が直 腸である67例中, 第 2 癌の最も頻度の高い部位は横行 結腸で16例 (24\%), 以下直腸13例 (19\%)，上行結腸 12 例 (18\%)，S 状結腸10例（15\%)，下行結腸 8 例 (12\%)，盲腸 7 例（10\%）であった。このように直腸 癌に対する第 2 癌は残存大腸のいずれの部位にも発生 し得る。しかし Miles 手術術後に人工肛門粘膜に腺癌 が新発生したといら報告はきわめて稀で, Takami ${ }^{4} か ゙$ 1983年に報告した 1 例のみである(表). Takami の症 例は, Miles 手術14年後に人工肛門の断端から発生し た数ミリメートルのポリーブ様病変が 3 年間に鵎卵 大，その後の 2 年間に急速に増大した点が注目に価す ると述べている，本症例は腺腫内癌であり，いわゆる adenoma-cancer sequence により癌が発生したと推 察し得る ${ }^{6)}$ ここのような变化がたまたま体表に露出し た大腸粘膜に生じた点が興味深い。

腹腔内の腸管粘膜に比し体表に露出した粘膜は日 
表 人工肛門に原発した腺演

\begin{tabular}{|c|c|c|c|c|c|c|}
\hline No. & 報告者 & 報告年 & 既 往 歴 & 年龄，性 & 主 & 手術 歴 \\
\hline 1 & Takami & 1983 & 直腸癌 & 38, 男 & 人工肛門部の腫瘤 & 19歳時 Miles 手術 \\
\hline 2 & Morgan & 1966 & 演富性大腸炎 & 76 , 女 & 人工肍門部の潰管 & 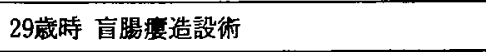 \\
\hline 3 & Sigler & 1969 & 潰塲性大晹炎 & 56 , 女 & 腹痛 & 37威時 回腸嫂造設術 \\
\hline 4 & Cuesta & 1976 & 潰場性大晹炎 & 60 , 男 & 人工肛門部の硬結 & 29葴時 回腸筎造設術 \\
\hline 5 & 自験例 & 1989 & 直晹密，盲腸癌 & 56 , 男 & 人工肛門部の出血 & 44歳時 Miles 手術, 46藏時結腸右半切除術 \\
\hline
\end{tabular}

常, 衣服による圧迫や不意の傷害をらける機会は圧倒 的に多い..このような物理的刺激により癌が発生する とすれば，人工肛門部に癌が頻発するはずであるが実 際はきわめて稀である。本症例は家族歷より cancer family syndrome ${ }^{78)}$ と考古られ, 大腸癌発生の確率は 一般より高率であったと推察される。このよ5な背景 のもとに，偶発的に人工肛門部に癌が発生したと考え るのが妥当である.

異時性多発大腸癌とは異なるが，潰瘍性大腸炎症例 に造設した人工肛門部に腺癌が新発生したといら報告 は，1966年以来 3 例認める.Morgan ${ }^{11}$ は76歳の女性の 盲腸瘦部の腺癌発生例を報告している. Sigler ${ }^{2}$ は22年 前に造設した回腸瘦部 $5 \mathrm{~cm}$ の範囲の回腸に高分化腺 癌を認めたと報告している。. Cuesta ${ }^{3 /}$ の報告例では31 年前に造設した回腸瘦部の回腸皮虚移行部に高分化腺 癌を認めた。

潰場性大腸炎の 3 例は，いずれる人工肛門造設後20 年以上経過していた。 また人肛門の管理として，な んら特別な処置は行われていなかった。これら 3 例は 潰痬性大腸炎の合併症としての癌化が, 体表に露出し た人工肛門部の腸管に発生したと考古られる。

本症例のごとく大腸癌ならびに潰瘍性大腸炎に対す る人工肛門造設術後には，きわめて稀ではあるが同部 に癌が発生することがあり, 観察の容易な人工肛門部 の診察には十分注意すべきである。

$$
\text { 結語 }
$$

直腸癌根治手術 12 年後に, 人工肛門粘膜に腺腫内癌 が発生したきわめて稀な症例を経験したので報告し
た.

\section{文 献}

1) Morgan MN : Carcinoma in a caecostomy in longstanding ulcerative colitis. Proc R Soc Med $59: 427,1966$

2) Sigler L, Jedd FL: Adenocaricnoma of the ileostomy occurring after colectomy for ulcerative colitis : Report of a case. Dis Colon Rectum 12 : 45-48, 1969

3) Cuesta MA, Donner R: Adenocarcinoma arising at an ileostomy site: Report of a case. Cancer 37: 949-952, 1976

4) Takami $M$, Hanada $M$, Kimura $M$, et al: Adenocarcinoma arising at a colostomy site: Report of a case. Dis Colon Rectum 26: 50-52, 1983

5) 大腸多発癌 フンヶート調查：第 16 回大腸癌研究 会, 米子, 1982

6) Muto T, Bussey HJR, Morson BC: The evolution of camcer of the colon and rectum, Camcer 36 : 2251-2270, 1975

7) Lynch HT, Lynch PM: The cancer-family syndrome: A pragmatic basis for syndrome identificaton. Dis Colon Rectum 22 : 106-110, 1979

8）杉野盛規，南俊之介, 中村正廣他：非ボリボージス 家族性大腸癌の 1 家系，日消外会誌 $22 ： 722$, 1989 


\title{
A CASE OF CARCINOMA IN ADENOMA ARISING IN ARTIFICIAL ANUS TWELVE YEARS AFTER RADICAL RESECTION OF RECTAL CANCER
}

\author{
Yukiyasu TAKEUCHI, Syunnosuke MINAMI, Seiki SUGINO, Akira KASHIWAI, Manabu TAKEDA, \\ Nobutaka HATANAKA, Hiroshi YOKOTA and Masato HANADA* \\ Department of Surgery, Higashi-Osaka Central Municipal Hospital \\ *Department of Pathology, Toyonaka Municipal Hospital
}

It is uncommon that an adenoma primarily arises in an artificial anus. We encountered such a rare case in a 56-year-old male who underwent Miles' operation for rectal cancer in 1975 and right hemicolectomy for cecal cancer in 1977. Both resections were curative and no signs of recurrence were observed after the operations. The patient visited our hospital because of hemorrhage from the artificial anus in 1987, and a thumb tipsized mass found at the site. Carcinoma in adenoma was diagnosed via biopsy. The artificial anus was dissected from the surrounding tissues and circumcised at $1 \mathrm{~cm}$ from the oral margin of the tumor. Pathohistological examination revealed a mucous cancer extending to the submucosa at the center of the adenoma. Adenoma arising in the artificial anus has only been reported in three cases of ulcerative colitis and one case after Miles' operation. It has not been reported that a carcinoma in adenoma has arisen in the artificial anus like this case. 